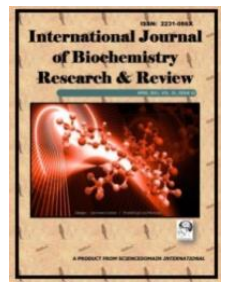

International Journal of Biochemistry Research

\& Review

5(4): 233-241, 2015, Article no.IJBcRR.2015.027

ISSN: 2231-086X

SCIENCEDOMAIN international

www.sciencedomain.org

\title{
Evaluation of Aqueous Leaf Extract of Cissampelos mucronata on Testicular Function Indices in Wistar Rats
}

\author{
T. D. Olaolu ${ }^{1 *}$, O. G. Akinwande ${ }^{1}$ and A. P. Olaolu ${ }^{2}$ \\ ${ }^{1}$ Department of Biological Sciences, Biochemistry Unit, Landmark University, Omu Aran, Kwara State, \\ Nigeria. \\ ${ }^{2}$ The Medical Unit, Landmark University Medical Centre, Omu Aran, Kwara State, Nigeria.
}

This work was carried out in collaboration between all authors. Author TDO designed the study, wrote the protocol and supervised the work. Author OGA carried out all laboratories work and performed the statistical analysis. Author APO managed the analyses of the study. Author TDO wrote the first draft of the manuscript. Author OGA managed the literature searches and edited the manuscript. All authors read and approved the final manuscript.

Article Information

DOI: $10.9734 / \mathrm{IJBCRR} / 2015 / 14318$

Editor(s):

(1) Carmen Lúcia de Oliveira Petkowicz, Federal University of Parana, Curitiba, Parana, Brazil. (2) Alfonso Clemente, Estación Experimental del Zaidín (EEZ-CSIC), Department of Physiology and Biochemistry of Animal Nutrition, Albareda, Granada, Spain. Reviewers:

(1) Anonymous, Federal University of Rio Grande do Norte, Natal-RN, Brazil. (2) Suresh Babu Sayana, Department of Pharmacology, Kims University, Karad,Maharashtra, India. (3) Anonymous, Beijing University of Chemical Technology, Beijing, China. (4) Anonymous, SRM University, Kattankulathur, India. Complete Peer review History: http://www.sciencedomain.org/review-history.php?iid=845\&id=3\&aid=7410

Original Research Article

Received $26^{\text {th }}$ September 2014 Accepted $28^{\text {th }}$ November 2014 Published 17 ${ }^{\text {th }}$ December 2014

\section{ABSTRACT}

Aim: This study aimed at investigating the effect of aqueous leaf extract of Cissampelos mucronata on testicular function indices in male wistar rats (Rattus novergicus).

Methodology: A total of 20 rats, grouped into four, with a group consisting of five rats were used for the study. The groups were a control administered $1.0 \mathrm{~mL}$ of distilled water and three other groups that were respectively administered $-1.0 \mathrm{~mL}$ of 300,600 and $1200 \mathrm{mg} / \mathrm{kg}$ body weight of the plant extract. The different groups were administered plant extract orally for 14 days, using metal oropharyngeal cannula. 
Results: The results revealed a significant increase $(P<0.05)$ in body weight, testes-body weight ratio, cholesterol and glycogen concentrations at all the doses except at $1200 \mathrm{mg} / \mathrm{kg}$ body weight of the animals where decreased glycogen level was observed. There was also significant decrease $(P$ $<0.05$ ) in the concentrations of acid phosphatase, alkaline phosphatase and total testicular protein especially in rats administered with $1200 \mathrm{mg} / \mathrm{kg}$ body weight of extract while there was no significant change in the activities of gamma glutamyl transferase. Serum testosterone concentration was observed to decrease significantly $(P<0.05)$ only in the rats administered with $300 \mathrm{mg} / \mathrm{kg}$ body weight of extract.

Conclusion: The results indicate anti-androgenic and anti-steroidogenic activities of Cissampelos mucronata aqueous leaf extract on males.

Keywords: Cissampelos mucronata; testicular function indices; anti-androgenic; anti-steroidogenic.

\section{INTRODUCTION}

Medicinal plants are the main source of healthcare for most developing countries [1] as a result of their low cost, safety, cultural acceptability and closer to nature properties. The World Health Organization reported that 70 $80 \%$ of the entire world population depends on traditional medicine as their primary healthcare and this is also inclusive of developed countries [2]. There has been an increase in the use of herbs and medicinal plants in developed countries and metropolitan areas of recent contrary to the fact that it was previously associated with rural areas [3].

Plants and plant products have been documented to possess curative properties including anti-sickling, anticancer, antimalarial, anti-diabetic, anti-hypertensive amongst others. Some secondary plant metabolites have been reported to be the probable source of their characteristic "healing virtue"; some secondary plant metabolites that make them highly beneficial to human health include alkaloids, flavonoids, tannins, glycosides, phenols, anthocyanins and several others. Several plants are known to possess the ability to modulate reproductive functions to various degrees in both males and females consequently leading to enhanced fertility or infertility. In males, some plants have been reported to enhance or hinder testicular functions, some of these include; Chromolaena odorata, Tecoma stans, Aeglemarmelos which have been reported to hinder testicular functions [4-6] whereas Fadogia agrestis, Rauvolfia vomitoria, Xylopia aethiopica enhance testicular functions $[1,7,8]$.

Infertility is defined as the inability of a couple to have a child or carry a pregnancy till full term after one year of regular sexual intercourse (three to four times a week) without contraceptives [9-11]. $20-30 \%$ of infertility cases have been attributed to male-related issues [12,13]. This includes problems with the testes since the testis is mainly involved in the production of androgens and spermatogenesis. Although several approaches for male infertility treatment have been investigated for a long period of time such as hormonal, surgical and chemical approaches; however, the high cost of orthodox medicine and unavailability of modern infrastructures exempt a large percentage of the population of developing countries from modern healthcare. Consequently, alternative medicine still remains a cheap and reliable source of healthcare for most developing countries.

Cissampelos mucronata (A. Rich) belongs to the family Menispermaceae, it is a perennial climbing plant with annual stem that scramble over the ground or twine into the surrounding vegetation for support. C. mucronata is widely distributed all through tropical and sub-tropical Africa, America and Asia $[14,15]$. The common English names are velvet leaf, ivy vine and heart-leaved vine. In Nigeria, the aqueous leaf extract of $C$. mucronatais commonly used in the treatment of female infertility issues especially in preventing miscarriages. Different parts of C. mucronata A. Rich, are commonly used in the tropics and subtropics to treat infirmities such as malaria, venereal diseases, gastro-intestinal complaints and menstrual problems [15]. Fractions of methanolic leaf extract of $C$. mucronata have been documented to demonstrate significant protection against ulcer induced indomethacin in rats [16]. The effect of the methanolic extract of the root of C.mucronata on embryofoetal development of rats was examined and the results showed that administration of the extract from gestation day 6 to 20 had no significant effect on the number of implantation sites while resorption sites were significantly high in a dose dependent manner [17]. The effect of orally 
administered aqueous extract of C. mucronata on the kidneys of adult female rats has also been evaluated with results revealing ruptured blood vessels with distorted cytoplasm compared with the control, exposing a deleterious effect on the kidneys of adult female wistar rats [18]. However, there is paucity of data on the effect of $C$. mucronata on the reproductive parameters of male wistar rats. This research was therefore aimed at evaluating the effect of aqueous leaf extract of $C$. mucronata on some testicular function indices of male wistar rats.

\section{MATERIALS AND METHODS}

\subsection{Plant Extract}

The plant samples were obtained from Landmark University, Omu-Aran, Kwara State, Nigeria, and authenticated at the Department of Plant Biology, Faculty of Life Sciences, University of Ilorin, llorin, Kwara state. A voucher specimen (UIH001/442) was deposited at the herbarium.

Prior to use, the sampled leaves of C. mucronata were first rinsed in distilled water to remove dirt and air dried at room temperature. The dried leaves were then pulverized, using an electric blender, out of which $188 \mathrm{~g}$ was extracted in $1000 \mathrm{~mL}$ distilled water for $48 \mathrm{~h}$ at room temperature. The resulting extract from the distillation was filtered with whatman No. 1 filter paper and the filtrate concentrated with a rotary evaporator to give a yield of $35 \mathrm{~g}$ of residue, brownish-black slurry. This was later reconstituted in distilled water to give the required doses of 300,600 and $1200 \mathrm{mg} / \mathrm{kg}$ body weight before oral administration to experimental animals.

\subsection{Experimental Design}

Male albino rats (Rattus norvegicus) of wistar strain weighing 140-200 g were obtained from the Animal Holding Unit of the Department of Biochemistry, Faculty of Science, University of Ilorin, Ilorin, Kwara state. Nigeria. Before the commencement of the experiment, the rats were acclimatized to the laboratory conditions (28$30^{\circ} \mathrm{C}$; $12 \mathrm{~h}$ natural light and $12 \mathrm{~h}$ dark; Humidity: $50-55 \%$ ) for two weeks with free access to rat chow and water ad libitum. The rats were used according to the Guide for the Care and Use of Laboratory Animals [19].

For the setup, the 20 rats were completely randomized into four groups of five rats each as follows:
- Group A: Control group administered $1 \mathrm{ml}$ of distilled water

- Group B: administered $300 \mathrm{mg} / \mathrm{kg}$ body weight of the extract

- Group C: administered $600 \mathrm{mg} / \mathrm{kg}$ body weight of the extract

- Group D: administered $1200 \mathrm{mg} / \mathrm{kg}$ body weight of the extract

The extracts (300, 600 and $1200 \mathrm{mg} / \mathrm{kg}$ body weight) were reconstituted in $1 \mathrm{~mL}$ each of distilled water and orally administered to the animals once daily for 14 days between 09:00 09:45 hours. The rats were sacrificed 24 hours after their last doses. The weight of the animals was taken and recorded once in two days. The oral administration of the extract on the rats was carried out by force-feeding, using cannula attached to graduated syringe.

\subsection{Experimental Assay}

The assay kits used for the determination of Cholesterol, Gamma-glutamyl transferase, and serum testosterone were products of Agappe Diagnostics Ltd, Switzerland. All other reagents used were of analytical grade and prepared in all glassware.

For serum preparation and testicular supernatant, the procedure described by [20] was employed. Under ether anesthesia, the neck areas were quickly cleared of fur and skin to expose the jugular veins. The jugular veins was slightly displaced from the neck region (to prevent contamination of the blood with interstitial fluid) and then cut with a sharp sterile blade. The rats were made to bleed into clean, dry corked centrifuge tubes which were left at room temperature for $10 \mathrm{~min}$. After that, the tubes were centrifuged at $224 \times g$ for $15 \mathrm{~min}$ using Laboratory Centrifuge (LW scientific centrifuge; Model: C5). The serum was thereafter collected using Pasteur pipettes into clean, dry, sample bottles and then used within 12 hours of preparation for the determination of the concentrations of the hormone.

Also, $24 \mathrm{~h}$ after the last day's administration $\left(15^{\mathrm{th}}\right.$ day), each animal was weighed and put under diethyl ether anesthesia. The rats were thereafter sacrificed and the testes carefully removed, and placed in cold $0.25 \mathrm{M}$ sucrose solution to maintain the integrity of the tissue of the testes. The testes were thereafter blotted with tissue paper and weighed to allow for the calculation of the testes-body weight ratio. The testes were homogenized in ice-cold $0.25 \mathrm{M}$ sucrose solution 
(1:5 w/v) using a Teflon homogenizer. The homogenates were centrifuged at $1340 \times \mathrm{g}$ for 15 minutes using a refrigerated centrifuge (Anke centrifuge; Model: TDL-5000B).The supernatant was kept frozen overnight before being subject to various biochemical assays.

In the determination of testicular parameters, the testes: body weight ratio was calculated as described by [21]. The concentration of testosterone was determined in accordance to the procedure outlined by the assay kit manufacturer's protocol; the analyzer was calibrated for use with animal sera instead of human sera. The concentrations of testicular total protein, total cholesterol and glycogen were determined using the procedures described by [22-24], respectively. The activities of GGT, ACP and ALP were also determined using the assay techniques described by [25-27] respectively.

\subsection{Ethical Consideration and Statistical Analysis}

For ethical consideration, before commencement of the study, the research proposal was submitted to the relevant research committee at the Landmark University, Omu Aran, Nigeria for approval to carry out the study. All ethical guidelines as required by the university were strictly adhered to.

Results were expressed as mean \pm standard deviation. Differences between normal and treated groups were the criteria for the pharmacological activities. Statistical analysis of results was carried out using the SPSS statistical software. Comparison of means were done using the One-Way Analysis of Variance (ANOVA). Differences with values of $P<0.05$ were considered statistically significant.

\section{RESULTS AND DISCUSSION}

The qualitative phytochemical analysis of the aqueous leaf extract of $C$. mucronata is shown in Table 1. As shown in the table, the plant extract was observed to contain high concentration of saponins and tannins while the flavonoids and steroids were found in moderately high concentration and trace amount, respectively.

As shown in Table 2, when compared with the control groups, the body weights of all the experimental animals were observed to increase The result of the effect of aqueous leaf extract of C. mucronata on the activity of enzymes is displayed in Table 4. As shown in the table, significantly across all the groups from day 1 to day 14. A similar trend was also observed with the testes-body weight ratio.

When investigating the effects of the extract on testicular cholesterol and serum testosterone concentration, the observation in the study revealed a significant increase in testicular cholesterol concentration than that of the control. The increase across all the groups was in a dose dependent manner from 3.93 to $4.34 \mathrm{mmol} / \mathrm{L}$ except in the case of Group C, which was 3.27 $\mathrm{mmol} / \mathrm{L}$. The serum testosterone was observed to display a reduction in concentration across all groups compared with the control, although this reduction was only observed to be significant in Group B (Table 3).

With respect to testicular protein and glycogen concentration, significant decreases in the concentration of testicular protein were only observed in Groups B and D. Generally, the lowest value testicular protein concentration of $6.35 \mathrm{mg} / \mathrm{mL}$ was observed in Group D while the highest value of testicular protein concentration $10.76 \mathrm{mg} / \mathrm{mL}$ was observed in Group C. In the case of testicular glycogen concentration, when compared with the control, a significant increase in Groups B and C and a decrease in Group D was observed (Table 4).

Three concentrations of the extract $(300 \mathrm{mg}, 600$ $\mathrm{mg}$ and $1200 \mathrm{mg}$ per kg-body weight) were used for the study. The choice of these concentrations was deliberate. An ethnobotanical survey of the plant carried out prior to the study revealed that the recommended safety oral dose of the extract was observed to be $600 \mathrm{mg} / \mathrm{kg}$. The choice of the higher and lower concentrations was to see if such doses have similar or divergent effect on the indices investigated in the study.

Table 1. The phytochemical composition of the aqueous leaf extract of $C$. mucronata

\begin{tabular}{ll}
\hline Phytochemical & Ethanol leaf extract \\
\hline Alkaloids & - \\
Flavonoids & ++ \\
Tannins & +++ \\
Saponins & +++ \\
Cardiac glycosides & - \\
Steroids & + \\
Anthraquinones & - \\
Terpenoids & - \\
\hline +++ = Present in high amount, ++ = present in moderately \\
\multicolumn{2}{l}{ high amount, + = present in trace amount, - = absent }
\end{tabular}

Gamma glutamyl transferase (GGT) was found to show increase in concentration within the 
treatment groups in a dose dependent manner with Group B having the lowest concentration of $170.46 \mathrm{U} / \mathrm{L}$ while Group D had the highest concentration of $193.85 \mathrm{U} / \mathrm{L}$. These increases were however not found to be significant. The concentration of Acid Phosphatase (ACP) displayed significant increases across all the treatment groups. The lowest concentration $3281.52 \mathrm{nM} / \mathrm{min} / \mathrm{ml}$ was observed in Group D while the highest concentration was observed in Group C. Although there was a decrease in Alkaline Phosphatase (ALP) concentration across all the treatment groups, this decrease was only observed to be significant in Group D (Table 5).
The results of this study show that the oral administration of aqueous extract of $C$. mucronata brought about a significant increase in the body weight of the animals, the testes-body weight ratio was also observed to increase significantly. The increase in the testes-body weight ratio observed following the administration of the plant extract may be due to improved secretory activity of the testes which may be explained by the rise in the testicular cholesterol and glycogen concentrations. This observation corroborates with the work of $[28,29]$ following the administration of aqueous extract of Massularia acuminata (G. Don) stem, Zingiber officinale and Pentadiplandra brazzeana in male rats respectively.

Table 2. Effect of aqueous leaf extract of $\boldsymbol{C}$. mucronata on body weight $(\mathrm{g})$ and testes-body weight ratio (\%)

\begin{tabular}{|c|c|c|c|c|}
\hline \multirow[t]{2}{*}{ Groups } & \multicolumn{3}{|c|}{ Body weight $(g)(n=5)$} & \multirow{2}{*}{$\begin{array}{l}\text { Testes-body weight } \\
\text { ratio (\%) }\end{array}$} \\
\hline & Day 1 & Day 7 & Day 14 & \\
\hline Group A & $193.93( \pm 15.67)$ & $196.32( \pm 15.20)$ & $202.88( \pm 17.07)^{*}$ & $1.28( \pm 0.19)$ \\
\hline Group B & $159.52( \pm 8.81)$ & $175.23( \pm 8.77)^{\star}$ & $181.91( \pm 12.86)^{*}$ & $1.66( \pm 0.22)^{*}$ \\
\hline Group C & $148.31( \pm 2.10)$ & $165.46( \pm 2.54)^{*}$ & $177.62( \pm 3.32)^{*}$ & $1.67( \pm 0.07)^{*}$ \\
\hline Group D & $139.94( \pm 6.40)$ & $155.40( \pm 8.33)^{*}$ & $162.31( \pm 15.24)^{*}$ & $1.72( \pm 0.09)^{*}$ \\
\hline
\end{tabular}

Table 3. Effect of aqueous leaf extract of C. mucronata on testicular cholesterol (mmol/L) and serum testosterone concentration $(\mathrm{ng} / \mathrm{ml})$

\begin{tabular}{lll}
\hline Groups & $\begin{array}{l}\text { Cholesterol concentration } \\
(\mathbf{m m o l} / \mathrm{L})\end{array}$ & $\begin{array}{l}\text { Serum testosterone } \\
\text { concentration }(\mathbf{n g} / \mathbf{m l})\end{array}$ \\
\hline Group A & $3.60( \pm 0.24)$ & $1.70( \pm 0.71)$ \\
Group B & $3.93( \pm 0.77)^{*}$ & $0.50( \pm 0.42)^{*}$ \\
Group C & $3.27( \pm 0.35)^{*}$ & $1.50( \pm 0.28)$ \\
Group D & $4.34( \pm 0.31)^{*}$ & $1.50( \pm 0.57)$ \\
\hline
\end{tabular}

Values are mean $\pm S D$ for each group of five rats. ${ }^{*}$ Means significantly different at $P<0.05$. Group, $A, B, C$ and $D$ represent administered with control (administered distilled water), $300 \mathrm{mg} / \mathrm{kg}, 600 \mathrm{mg} / \mathrm{kg}$ and $1200 \mathrm{mg} / \mathrm{kg}$ body weight of the extracts, respectively.

Table 4. Effect of aqueous leaf extract of C. mucronata on total protein $(\mathrm{mg} / \mathrm{ml})$ and glycogen concentration $(\mathrm{mg} / \mathrm{ml})$

\begin{tabular}{|c|c|c|}
\hline $\begin{array}{l}\text { Groups } \\
\text { (mg/kg b. wt) }\end{array}$ & Testicular Protein (mg/ml) & $\begin{array}{l}\text { Testicular Glycogen } \\
\text { concentration }(\mathrm{mg} / \mathrm{ml})\end{array}$ \\
\hline Group A & $10.46( \pm 3.24)$ & $3.46( \pm 2.02)$ \\
\hline Group B & $7.65( \pm 1.43)^{*}$ & $5.86( \pm 1.96)^{*}$ \\
\hline Group C & $10.76( \pm 2.33)$ & $5.56( \pm 2.77)^{\star}$ \\
\hline Group D & $6.35( \pm 0.80)^{*}$ & $2.31( \pm 0.43)$ \\
\hline
\end{tabular}


Table 5. Effect of aqueous leaf extract of $C$. mucronata on the activity of enzymes - Gamma glutamyl transferase GGT (U/L), Acid Phosphatase ACP (nM/min/ml), Alkaline Phosphatase $\operatorname{ALP}(\mathrm{nM} / \mathrm{min} / \mathrm{ml})$

\begin{tabular}{|c|c|c|c|}
\hline $\begin{array}{l}\text { Groups } \\
\text { (mg/kg b. wt) }\end{array}$ & $\begin{array}{l}\text { GGT } \\
\text { (U/L) }\end{array}$ & $\begin{array}{l}\text { ACP } \\
\text { (nM/min/ml) }\end{array}$ & $\begin{array}{l}\text { ALP } \\
\text { (nM/min/ml) }\end{array}$ \\
\hline Group A & $167.14( \pm 27.64)$ & $4090.76( \pm 910.16)$ & $3627.53( \pm 1132.42)$ \\
\hline Group B & $170.46( \pm 38.06)$ & $3332.00( \pm 286.03)^{*}$ & $2848.49( \pm 294.99)$ \\
\hline Group C & $187.50( \pm 29.99)$ & $3894.02( \pm 223.82)^{*}$ & $2955.81( \pm 695.47)$ \\
\hline Group D & $193.85( \pm 52.15)$ & $3281.52( \pm 595.34)^{*}$ & $2430.30( \pm 287.49)^{*}$ \\
\hline
\end{tabular}

The significant decline in testicular protein at $1200 \mathrm{mg} / \mathrm{kg}$ body weight of the plant may indicate the absence of spermatozoa in the lumen since the luminal fluid of the epididymis contains a number of proteins [6]. Testicular proteins are required for sperm maturation and spermatogenesis [30], therefore the significant decline in testicular protein observed in this study may imply animpairment in sperm maturation indicating the anti-androgenic nature of the plant extract, this may be further explained by the significant decrease in testosterone concentration observed in the present study which is a marker of androgenicity [31]. Similar result was observed with Nyctanthes arbor-tritis stem bark [32] and aqueous root extract of Lecaniodiscus cupanioides [33].

Following the administration of Cissampelos mucronata aqueous leaf extract (CMALE) at 300 and $600 \mathrm{mg} / \mathrm{kg}$ body weight, the significant increase in testicular glycogen may be ascribed to the stimulation of phosphorylase and an inhibitory action of glycolysis [34] due to the presence of cholesterol which is an alternative source of energy. However, the reduction in glycogen concentration following the administration of the extract at $1200 \mathrm{mg} / \mathrm{kg}$ body weight probably suggests that the extract has reached a level to start exerting toxic effect on the testes and this may be attributed to its saponins content as reported by Gupta and colleagues [35] where saponin content of the bark of Albizia lebbeck (L.) Benth (Mimosoideae) decreased glycogen and inhibited glycolysis during spermatogenesis.

The significant increase in testicular cholesterol concentration in the extract-treated rats reflects the reduced conversion of cholesterol to androgens or the arrest of steroidogenesis of testosterone [36], leading to the accumulation of cholesterol in the testis. This may be the explanation for the low testosterone level observed in C. mucronata treated rats. A similar result was reported by Sonalika and co-workers [37] with the aqueous extract of Calendula officinalison the reproductive function of adult male rats. This may be an indication of the extract's ability in impairing the steroidogenesis process.

The decrease in the testicular alkaline phosphatase activity at $1200 \mathrm{mg} / \mathrm{kg}$ body weight may imply reduction in the recruitment of carbohydrates, lipids and other metabolites necessary for steroidogenesis and for use by other accessory sex structures. This may seem to explain the decrease in testosterone concentration observed in this study, showing the ability of the extract to inhibit intracellular and intercellular transport of metabolites required for steroidogenesis. This correlates with the report of Nurudeen and Ajiboye [33] where Lucaniodiscus cupanioides restores sexually impaired male rats by significantly attenuating paroxetine-mediated decrease in alkaline phosphatase.

The observed decrease in acid phosphatase in this study may be a result of impaired steroidogenesis and anti-anabolic effect of the plant extract; this is because improvement in steroidogenesis has been associated with increase in acid phosphatase [5]; increased level of acid phosphatase has also been linked to anabolic effect of the plant [38].

The non-significant increase in the activity of testicular GGT may indicate that the plant extract had no significant influence on the sertoli cells function, this may not be favorable for proper functioning of the sertoli cells and consequently spermatogenesis by hindering its supportive role and the carriage of spermatozoa into the rete testes [28]. 
The decrease in testosterone concentration in this study may be due to decreased number of Leydig cells, this is line with the report of Marthur and colleagues [34], where the number and nuclei diameter of Leydig cells were reduced in Tecomastans treated rats leading to a depletion of the testosterone levels. This may also be attributed to the high saponin content of the extract as supported by the report of Gupta et al. [35], where saponin content of the bark of Albizia lebbeck (L.) Benth (Mimosoideae) decreased Leydig cell nuclear area and number of mature Leydig cells. The decreased testosterone concentration may also be explained by the inhibition of steroidogenesis as a result of testicular cholesterol accumulation observed in this study. Testosterone is known as a very important marker of androgenicity, therefore this result may imply the anti-androgenic nature of the plant extract on male wistar rats.

\section{CONCLUSION}

The results of this study indicate anti-androgenic and anti-steroidogenic effect of CMALE on male rats with the $1200 \mathrm{mg} / \mathrm{kg}$ body weight of the extract exhibiting the highest anti-androgenic and anti-steroidogenic activities. This implies that the use of $C$. mucronatain the management of male sexual dysfunction and infertility just as it had previously been used for female infertility issues is not supported. Therefore, the oral administration of CMALE may help to regulate fertility in males due to its ability to arrest steroidogenesis and interfere with levels of androgens and other testicular function indices; this could result in impaired spermatogenesis in the testes hindering reproductive activity in male rats.

\section{COMPETING INTERESTS}

Authors have declared that no competing interests exist.

\section{REFERENCES}

1. Lembe DM, Koloko BL, Bend EF, Domkam J, Oundoum PC, Njila MN, Moundipa P, Dimo T, Gonzales GF. Fertility enhancing effects of aqueous extract of Rauvolfia vomitoria on reproductive functions of male rats. Journal of Experimental and Integrative Medicine. 2014;4(1):43-49.

2. WHO. Traditional Medicine Strategy 20022005. Geneva: WHO; 2002.
3. Harnack LJ, Rydell SA, Stang J. Prevalence of use of herbal products by adults in the Minneapolis/St Paul, Minn, metropolitan area. Mayo Clin. Proceed. 2001;76:688-694.

4. Yakubu MT. Effect of a 60-day oral gavage of a crude alkaloid extract from Chromolaena odorata leaves on hormonal and spermatogenic indices of male rats. Journal of Andrology. 2012;33(6):11991207.

5. Mathur PP, Chattopadhyay S. Involvement of lysosomal enzymes in flutamide-induced stimulation of rat testis. Andrologia. 1982;14:171-176.

6. Chauhan A, Agarwal M, Kushwaha $S$, Mutreja A. Antifertility studies of Aegle marmelos Corr, and Indian medicinal plant on male albino rats. Egyptian Journal of Biology. 2008;10:28-35.

7. Yakubu MT, Akanji MA, Oladiji AT. Aphrodisiac potentials of the aqueous extract of Fadogia agrestis (Scweinf. Ex Hiern) stem in male albino rats. Asian Journal of Andrology. 2005;7:399-404.

8. Woode E, Alhassan A, Abaidoo CS. Effect of ethanolic fruit extract of Xylopia aethiopica on reproductive function of male rats. International Journal of Pharmaceutical and Biomedical Research. 2011;2(3):161-165.

9. Salgado JTR, Hernandez M, Ayala A. Frequency of altered male factor in infertility clinic. Obstetrics and Gynecology. 2003;71:233-237.

10. Ojobo S. Management of Infertility amongst Nigerian Couples, The way forward. Women's Health and Action Research Centre WHARC. Community Education Lecture Series. 2007;26.

11. Gaware VM, Parjane SK, Merekar AN, Pattan SR, Dighe NS, Kuchekar BS, Godge RK. Female infertility and its treatment by alternative medicine: $A$ review. Journal of Chemical and Pharmaceutical Research. 2009;1(1):148162.

12. Aubuchon M, Burney RO, Schust DJ, Yao MWN. Infertility and assisted reproductive technology, Berek and Novak's Gynecology. 15th ed. South Asian edition, SAE: Wolters and Kluwer Health. 2012;1139.

13. Dubey P, Gupta N, Dwivedi S, Swaroop N, Lal P, Thawani V. Hyperhomocysteinemia: a risk factor in unexplained infertility. International Journal of Reproduction, 
Contraception, Obstetrics and Gynecology. 2013;2(2):165-171.

14. Muthaura CN, Rukunga GM, Chabra SC, Mungai GM, Njagi ENM. Traditional antimalarial phytotherapy remedies used by the Kwale community of the Kenyan Coast. Journal of Ethnopharmacology. 2007;114:377-386.

15. Nondo RSO, Mbwambo ZH, Zidukuli AW, Innocent EM, Mihale MJ, Erasto P, Moshi MJ. Larvicidal, antimicrobial, brine shrimp activities of extracts from Cissampelos mucronata and Tephrosia villosa from coast region, Tanzania. BMC complementary and Alternative medicine. 2011;11:33.

16. Nwafor SV, Akah PA. Studies on antiulcer properties of Cissampelos mucronata leaf extract. Indian Journal of Experimental Biology. 1999;37:936-939.

17. Garba SH, Jacks TW, Onyeyili PA, Nggada HA. Embryofetal effects of the Methanolic root extract of Cissampelos mucronata A. $\mathrm{RICH}$ in rats. Anatomy Journal of Africa. 2014;3(1):286-293.

18. Falana BA, Caxton-Martins EA, Ofusori DA. Microanatomical effects of aqueous extracts of the leaves of Cissampelos mucronata on the kidney of adult female wistar rats (Rattus norvegicus). Scientific Research and Essay. 2011;6(13):26192623.

19. National Research Council (NRC). Guide for the care and use of laboratory animals. $8^{\text {th }}$ Edition. Washington: National Academies Science Press. 2011;161-196.

20. Yakubu MT, Akanji MA. Effect of aqueous extract of Massularia acuminata stem on sexual behavior of male wistar rats. Evidence-Based Complementary and Alternative Medicine. 2011;738:103. DOI:10.1155/2011/738103.

21. Yakubu MT, Akanji MA, Oladiji AT. Effect of oral administration of aqueous extract of Fadogia agrestis stem on some testicular function indices of male rats. Journal of Ethnopharmacology. 2008;111(2):288-292.

22. Gornal AC, Bardawill CJ, David MM. Determination of serum protein by means of biuret reaction. Journal of Biological Chemistry. 1949;177:751-756.

23. Fredrickson DS, Levy RI, Lees RS. Fat transport in lipoproteins-anintegrated approach to mechanisms and disorders. New England Journal of Medicine. 1967;276:148-156.
24. Kemp A, Adrienne JM, Heijningen KV. A colorimetric micro-method for the determination of glycogen in tissues. Biochemical Journal. 1954;56:646-648.

25. Szasz G. A kinetic photometric method for serum gamma-glutamyl transpeptidase. Clinical Chemistry. 1969;22:124-136.

26. Wright PJ, Leathwood PD, Plummer DT. Enzymes in rat urine. Acid phosphatase. Enzymologia. 1972a;42:459-462.

27. Wright PJ, Leathwood PD, Plummer DT. Enzymes in rat urine: Alkaline phosphatase. Enzymologia. 1972;42:317327.

28. Yakubu MT, Akanji MA, Oladiji AT, Adesokan AA. Androgenic potentials of aqueous extract of Massularia acuminate (G Don) Bullock ex Hoyl. stem in male wistar rats. Journal of Ethnopharmacology. 2008b;118(3):508-13.

DOI:10.1016/j.jep.2008.05.020.

29. Kamatchouing $P$, Fandio YM, Dimo $T$, Jatsa HB. Evaluation of androgenic activity of Zingiber officinale and Pentadiplandra brazzeana in male rats. Asian Journal of Andrology. 2002;4:299-301.

30. Kasturi M, Manivannan B, Ahmed NR, Shaikh PD, Pattan KM. Changes in epididymal structure and function of albino rat treated with Azardirachta indica leaves. Indian Journal of Experimental Biology 1995;33(10):725-729.

31. Walton S, Cunliffe WJ, Kaczkes K, Early AS, McGarrigle HHG, Katz M. Clinical, ultrasound and hormonal markers of androgenicity in acne vulgaris. British Journal of Dermatology. 1995;133(2):249253.

32. Gupta RS, Kachhawa JB and Sharma R. Antispermatogenic effects of Nyctanthes arbor-tristis in male albino rats. Pharmacology online. 2006;2:261-273.

33. Nurudeen QO, Ajiboye TO. Aqueous root extract of lecaniodiscus cupanoides restores the alterations in testicular parameters of sexually impaired male rats. Asian Pacific Journal of Reproduction. 2012;1(2):120-124.

34. Mathur N, Jain GC, Pandey G. Effect of Tecoma stans leaves on the reproductive system of male albino rats. International Journal of Pharmacology. 2010;6(2):152156.

35. Gupta RS, Chaudhary R, Yadav RK, Verma SK, Dobhal MP. Effect of saponins of Albizia lebbeck (L.) Benth bark on the reproductive system of male albino rats. 
Journal of Ethnopharmacology. 2005;96: 31-36.

36. Upta RS, Sharma R, Sharma A, Bhatnagar A, Dhobal MP, Joshi YC and Sharma MG. Effect of Alstonia scloris bark extract on testicular function of wistar rats. Asian journal of Andrology. 2002;4(3):175-8.

37. Sonalika K, Meera A, Priyanka S. Influence of aqueous extract of Calendula officinalis (flower) on the reproductive function of adult male rats. Asian Journal of Science and Technology. 2012;4(12):020-023.

38. Yakubu MT, Afolayan AJ. Anabolic and androgenic activities of Bulbine natalensis stem in male wistar rats. Pharmaceutical Biology. 2010;48(5):568-576.

(c) 2015 Olaolu et al.; This is an Open Access article distributed under the terms of the Creative Commons Attribution License (http://creativecommons.org/licenses/by/4.0), which permits unrestricted use, distribution, and reproduction in any medium, provided the original work is properly cited.

Peer-review history:

The peer review history for this paper can be accessed here:

http://www.sciencedomain.org/review-history. php ?iid=845\&id=3\&aid $=7410$ 